\title{
Millennials in the Workplace: A Communication Perspective on Millennials' Organizational Relationships and Performance
}

\author{
Karen K. Myers • Kamyab Sadaghiani
}

Published online: 5 March 2010

(C) The Author(s) 2010. This article is published with open access at Springerlink.com

\begin{abstract}
Stereotypes about Millennials, born between 1979 and 1994, depict them as self-centered, unmotivated, disrespectful, and disloyal, contributing to widespread concern about how communication with Millennials will affect organizations and how they will develop relationships with other organizational members. We review these purported characteristics, as well as Millennials' more positive qualities - they work well in teams, are motivated to have an impact on their organizations, favor open and frequent communication with their supervisors, and are at ease with communication technologies. We discuss Millennials' communicated values and expectations and their potential effect on coworkers, as well as how workplace interaction may change Millennials.
\end{abstract}

Keywords Communication - Millennial generation ·

Workplace communication - Intergenerational

communication · Organizational communication

Among many functions of communication in organizations and work groups, including information sharing, decision making, influence, coordination, motivation, and identification (Cheney et al. 2004; Miller 2009; Scott et al. 1998), communicative interactions in the workplace serve to

\footnotetext{
K. K. Myers $(\square)$

Department of Communication, University of California, Santa Barbara, 4005 SS \& MS, Santa Barbara, CA 93106, USA

e-mail: myers@comm.ucsb.edu

K. Sadaghiani

39 Coronado Pointe, Laguna Niguel, CA 92677, USA

e-mail: thekamyab@gmail.com
}

create and maintain work relationships among team and organizational members, and between those members and key organizational stakeholders (Myers 2009; Sias 2009). In particular, communication that reveals shared values and reflects common commitments to organizational goals enables coworkers to forge and sustain productive relationships in organizations (Herriot 2002). Communication can also have direct and indirect effects on team and organizational performance (Greenbaum and Query 1999). Furthermore, interactions and relationships in the workplace are influenced by numerous individual differences in communication, and these have been found to affect coworkers' satisfaction and productivity (Jablin and Krone 1994).

Millennials, born between 1979 and 1994 (Smola and Sutton 2002), have been described in both the popular literature and the popular press (see definitions in footnote 1) as the "Look at Me" generation, implying that they are overly self-confident and self-absorbed (Pew Research Center 2007). They also have been depicted as lacking in loyalty and work ethic (Marston 2009). As Millennials continue to enter the workplace, there is widespread speculation and some concern about how Millennials' predispositions and behaviors-including their communication orientations and skills-will affect other organizational members (especially those of older Boomer and Gen $\mathrm{X}$ cohorts). In the main, these concerns focus on Millennials' abilities to create functional work relationships with older employees and to enhance organizational performance (McGuire et al. 2007). Questions have been raised about how management can best motivate Millennials, as well as how Millennials' described "unique" qualities will translate to organizational membership and commitment. Although recent economic conditions may cause them to be more compliant than people had speculated they would 
be (Koch 2009; George 2008), some contend that Millennials' characteristics may complicate, and potentially disrupt, workplace interactions with members of other generations, thus negatively affecting coworkers and organizational processes (Alsop et al. 2009; McGuire et al. 2007). For example, popular perception (that is not supported by substantial evidence) is that Millennials are impatient, self-important, and disloyal, among other unattractive qualities from an organizational standpoint (Hill 2008; Howe and Strauss 2007; Jacobson 2007). Some organizations believe that to thrive and fully utilize Millennials' unique abilities, they may need to alter their rules and policies (Gursoy et al. 2008). In addition, popular perceptions of Millennials are not entirely negative. There also are popular depictions of Millennials' purported admirable attributes from organizations' perspectives, including beliefs that they are more accepting of diversity than were past generations, have capabilities with advanced communication and information technologies, have the ability to see problems and opportunities from fresh perspectives, and are more comfortable working in teams than were past generations (Howe and Strauss 2000; Gorman et al. 2004; Tapscott 1998; Zemke et al. 2000).

In this article we examine these and other attributes commonly associated with Millennials-characteristics that many people believe are likely to affect not only Millennials' ability to perform productively in organizations, but also their ability to develop effective organizational relationships. We explore how people speculate that Millennials are likely to be perceived by supervisors and coworkers and, based on their values and lived experiences, how people think that Millennials may respond to, and be affected by, those and other factors in the contemporary workplace. While engaging potential shortcomings of the Millennial generation, we emphasize how Millennial values and behavioral tendencies can enhance organizations through the quality of Millennials' relationships in the workplace and their effects on productivity. In the process, we set an agenda for Millennial-focused workplace interaction research, and call for investigations centered on benefits offered by Millennial participation and opportunities for organizations. Throughout our discussion, we take a communication perspective and highlight messages, meanings, and interactions likely to be central to the dynamics we describe involving Millennials and other generational cohorts in the workplace. We reference a variety of sources which we group into three categories including (1) popular press and (2) popular literaturearticles and books that are more opinion than evidencebased and have contributed to stereotypes, many without empirical support, about the generation. When possible, we draw on (3) empirical studies - peer-reviewed, data-based research with more rigorous methods-for more credible perspectives on Millennial communication and behaviors. ${ }^{1}$ We frequently refer to these three classifications thereby enabling readers to evaluate the strength of various claims. We include popular literature and reports because there is so little empirical evidence, but inclusion of the references should not necessarily be taken as endorsement of this study or agreement with the ideas described in this study.

We pursue these aims by treating the intersection of Millennials' characteristics and communication-related dynamics in five areas that are especially relevant for performance and member relationships in contemporary organizations: (1) socialization and membership negotiation by organizational members; (2) employment expectations and processes of relationship development in the workplace; (3) use of advanced information and communication technologies; (4) reactions to the current job market and implications of their full-time employment; and (5) orientation toward achievement and their aspirations for engaging in leadership (and the communicative role of Millennials' parents in developing these). We conclude by outlining an agenda for research on Millennials' organizational communication, relationships, and performance.

\section{Millennials, Communication, and Membership Negotiation}

As Millennials enter the workplace, like generations before them, the first significant hurdle they encounter is their socialization into the organization (Chao et al. 1994; Van Maanen and Schein 1979). Newcomers learn about tasks and social norm expectations through socialization processes, as well as how to adapt to and negotiate their roles

\footnotetext{
${ }^{1}$ We distinguish three source types. Popular press items include online articles and blogs, newspaper articles, and non-expert magazine columns. While these might allude to surveys or empirical studies, they are primarily entertainment-focused and should not be considered as substantive evidence of differences among the generations. They attract attention by making surprising or interesting claims and offering prescriptive advice, often based on no evidence beyond an individual's opinion or personal experience. These sources are the most common, but they are the least reliable. Popular literature includes books and articles that are written for trade and other audiences. These works base their claims on secondary research including surveys and even more empirical studies. We also include in this group commercially administered surveys and associated reports. The credibility of these sources is somewhat suspect because the authors/organizations may not be trained in empirical methods and data interpretation. Furthermore, the authors/organizations are driven by sales of their books, reports, and magazines so their claims and conclusions can be over-stated. Empirical studies or research offer the most powerful evidence. These studies are theory-driven and rely on sound social scientific methods. They are either peer-reviewed or were the basis of dissertations or theses, and therefore subject to expert scrutiny. Although we prefer these sources, they are the fewest in number.
} 
(Black and Ashford 1995; De Vos et al. 2003; Miller et al. 1999), and how to gain others' acceptance of them as participating members in the workplace (Moreland and Levine 1982, 2001; Myers and Oetzel 2003). Organizational socialization is interactive, involving newcomers' and old-timers' evaluations and commitments to each other and to the organization, as well as newcomers' potential transition to important roles in the organization (Moreland and Levine 1982, 2001; Myers 2006).

The ongoing, interactional communication processes among members during socialization has been termed membership negotiation-the intentional and unintentional processes through which individuals engage, disengage, and accomplish reciprocal, but still asymmetrical, influence over the intended meanings of an individual's participation in organizational functions (McPhee and Zaug 2000). Through membership negotiation processes, incumbent members determine who will likely fit in, both functionally and socially, to benefit the organization (Slaughter and Zickar 2006). Newcomers also engage in evaluations, assessing not merely job-related tasks and responsibilities, but also the organization and whether they will like working with coworkers and supervisors (Robinson and Morrison 2000; Scott and Myers 2010). Values held by newcomers and old-timers affect these evaluations and the success of these "negotiations" concerning membership (Allen 1995; Bouwhuis and Rink 2009; Cox 1994; Rink and Ellemers 2009). Therefore, newcomers' acceptance by coworkers is not guaranteed, as evidenced by the fact that some recruits become more central to their organizations while others remain on the periphery, never accepted as fully participating members (Allen 1995; Van Maanen and Schein 1979). When coworkers' work-related values and role expectations do not mesh, conflict, mistrust, and lower productivity can result (Hill 2002).

Trade journals and blogs claim that differences in values between Millennials and older generations of workers are affecting Millennials' membership negotiation and their acceptance by incumbent workers (Jacobson 2007; McGuire et al. 2007; Zwilling 2009). Their differing experiences and values can affect their perspectives, their evaluation of coworkers, and their organizational expectations. For example, some management-targeted websites forewarn that Millennials may desire more flexible working conditions and hours (e.g., working from remote locations, working into the evening but not early mornings) than have been normative in most organizations (Simmons 2008). However, when Millennials communicate and act according to their backgrounds and values, others' assessments of them may reflect expectancy violations (e.g., Burgoon 1993; Burgoon et al. 2000). According to expectancy violation theory, individuals are judged based on beliefs and contextual norms about appropriate behaviors in given circumstances. When members violate others' expectations of appropriate behavior, others' attributions and responses toward that member are affected (Leets 2001). Behaviors that are negatively assayed because they violate expectations cause the violator to be judged more negatively than if he or she had met standard expectations (Burgoon 1993). Moreland and Levine's (2001) research illuminates these dynamics. Early on, organizational incumbents assess every newcomer's ability to benefit the workgroup. Only when the new member is deemed valuable to the workgroup and organization, according to Moreland and Levine, do others reciprocate the relationship with commitment. Coworkers begin to ask for the new member's opinions, delegate significant tasks to the new member, and develop meaningful working relationships with the new member. This acceptance can be stifled when interaction reveals important differences in attitudes and behaviors.

A pertinent example of attitudinal and value differences related to Millennials that may affect membership negotiation is that, according empirical and popular press sources, more senior workers' believe that Millennial newcomers should have to "pay their dues" as they did when they were young workers (Marston 2007). Academic sources explain that "career" plays a significant role in Boomers' lives and is an essential component of their identities (Collinson and Hearn 1994). Boomer workers are depicted as having routinely sacrificed on behalf of the firm, working 55- to 60-h weeks, and they frequently advise young coworkers to work hard, demonstrate their dedication, and patiently wait their turn for promotions (Chatman and Flynn 2001). However, Millennials, much like Generation X workers, may not share Boomers' beliefs and values; building a career is not a primary motivator for most Millennials ${ }^{2}$ (Marston 2007). Instead, and as touted in popular literature, work is a less significant part of their personal identities, instrumental to supporting the lifestyle they desire (Marston 2007). Empirical studies demonstrate that throughout their careers, many Boomers have embraced competitiveness, and have focused on climbing organizational ranks (Gursoy et al. 2008). They are the original workaholics who, even as young adults, had little notion of work-life balance (McGuire et al. 2007; Stauffer 1997).

In contrast, Millennial workers are likely to communicate an interest in flexible career paths because their priority is work-life balance (Carless and Wintle 2007; Smola

\footnotetext{
${ }^{2}$ Although some suggest that these differences might be a result of stage in life, empirical research by Wentworth and Chell (1997), found that these were to be more strongly associated with generational differences.
} 
and Sutton 2002). A recent Gallup poll found that Millennials desire a work-life balance that will allow them to balance play with work (Ott et al. 2008). Millennial-written blogs and popular press articles attest that they also freely and openly admit that they prioritize close personal relationships over career ("Cara" 2009; Raines 2002). Their coworkers may initially respond to Millennials' work-life balance attitude with resistance (Alvesson and Willmott 2002; Smola and Sutton 2002). In particular, Boomer coworkers who often are in leadership positions, may question Millennials' commitment and dedication to the organization, dismissing Millennial workers as selfish or lazy (Collinson and Collinson 1997; Raines 2002). Their subsequent interactions with Millennial coworkers may reflect a level of discomfort, disrespect, or even distrust. It is possible that Boomer generation workers will never completely accept new colleagues who do not share their work ethic. While this might be true for any newcomers with significantly different values, many Millennials may remain somewhat marginalized by their older and more senior coworkers, making it more difficult for Millennials to earn workplace respect and credibility. This is especially problematic because a lack of informal communication in organizations is negatively related to member satisfaction (see Pace and Faules 1994), and low levels of communicative support from supervisors in particular is associated with job turnover (Clampitt 2005). Of course, Millennials who are astute and realize how their coworkers view them may make concerted efforts to demonstrate their value and willingness to contribute-just as employees who experience concertive control from coworkers in team-based organizations endeavor to conform to team norms and expectations (Barker and Cheney 1994). Millennials may not place as much value on "work" as their supervisors have, but they may find themselves accommodating the demands of the workplace and behaving more like Boomers once they become committed to particular projects and goals.

At the same time, and as part and parcel of the membership negotiation process (Scott and Myers 2010), Millennials may be a source of change within their organizations in several ways. First, engagement with Millennial workers who spend more time with their families and friends, and have diverse personal interests outside the workplace, may cause more senior workers to reconsider their own values. Boomers especially, may find themselves asking whether their extensive sacrifices have brought about lasting happiness and other benefits that they had hoped for (Collinson and Collinson 1997). Already some Boomers may have had this realization and might have taken cues from Millennials about how to create balance between their personal and work lives; more Boomers may follow. In addition, although recent economic turbulence and widespread job layoffs may cause some workers to put in extra hours to demonstrate their worth, popular literature suggests other long-time dedicated workers may question the wisdom of devoting $10-12 \mathrm{~h}$ a day for up to 50 years of their lives to organizations that may not offer the security long promised (Sennet 2000). Second, more senior workers may rebel against Millennials and argue that it is their younger colleagues' turn to make sacrifices and to accept responsibility for performance outcomes: "It's on their shoulders if deadlines are missed." Third, and consonant with employees' use of communication for resistance to organizational practices (Ganesh et al. 2005; Stohl and Cheney 2001), Millennials' push for work-life balance may attract the attention of management who may already be feeling pressure to alter official discourses that normalize "workaholic" behaviors and villainize workers who take advantage of family leave policies (Kirby and Krone 2002). Some organizations are finding human resource advantages to relaxing normative expectations concerning working over-time. For example, international accounting and consulting firm Deloitte and Touche significantly improved its $33 \%$ turnover rate for women when it redressed the implicit requirement that members work 80 -h work weeks (Babcock and Laschever 2003). The firm changed its formal policies, as well as the way that overtime work was valued in unofficial organizational discourse.

Empirical research by Twenge and colleagues (Twenge and Campbell 2001; Twenge and Nolen-Hoeksema 2002) and Twenge (2000) found that following more than a decade of historical events and cultural changes that negatively impacted children's sense of well-being, the 1980s adolescents and young adults have reported higher levels of self-esteem and lower levels of depression. While those studies gathered data only from college students, and levels of confidence may change considerably once students enter the workplace, other research also supports the conclusion that Millennials are unusually and extraordinarily confident of their abilities (George 2008; Greenfield 1998). Greenfield proposes that this confidence has been buoyed by an educational system with inflated grades and standardized tests, in which many Millennials are expert in performing well. The idea of paying their dues by working hard to demonstrate their worth before they are given significant tasks is likely to be resisted by Millennials, critics in the popular literature contend (Marston 2007; Martin 2005). Millennials may surprise their Boomer and Gen X managers when, according to Gallup polls, they seek key roles in significant projects soon after their organizational entry and very early in the membership negotiation process (Ott et al. 2008). Coworkers see them as overly confident and inappropriately demanding, asking "Who do they think they are?" (Alsop et al. 2009). 


\section{Millennials' Expectations, Communication, and Team Relationships}

Millennials' attributes and expectations that are likely to affect the development of workplace relationships with team and organizational members from other generations also have become focal issues (e.g., Gursoy et al. 2008; Howe and Strauss 2007; Stein and Beradinelli 2009). Popular literature and empirical research indicate that three Millennial preferences are likely to be especially significant for workplace interaction and the development of work relationships. First, Millennials expect close relationships and frequent feedback from supervisors (Society for Human Resource Management [SHRM] 2009). Second, they expect open communication from their supervisors and managers, even about matters normally reserved for more senior employees (Gursoy et al. 2008; Martin 2005; Remo 2006; SHRM, 2009). Third, Millennials prefer to work in teams, in part because they perceive group-based work to be more fun, but also because they like to avoid risk (Alsop 2008; Gursoy et al. 2008). Although workers of other generations may have shared some of these inclinations, what may be important is the widespread anticipation about Millennials' expectations relative to these communicative partialities, based on popular press stories. We explore these preferences below, paying special attention to their potential effects on Millennials and coworkers' relationships and performance.

Empirical studies have found that Millennials, not unlike employees of previous generations, view strong relationships with supervisors to be foundational for negotiating their roles initially, as well as for their longterm satisfaction in the organization (Jokisaari and Nurmi 2009; Martin 2005). In general, subordinates' job satisfaction is higher when supervisors are "open" in their communication with employees: sharing information, conveying bad news, evaluating job performance regularly, creating a supportive climate, soliciting input, and making appropriate disclosures (Jablin 1987). What is different is that according to popular literature and empirical research, Millennials expect communication with supervisors to be more frequent, more positive, and more affirming than has been the case with employees of prior generations (Deloitte 2009; Gursoy et al. 2008; Hill 2002; Marston 2007; Martin 2005; Remo 2006). Even acknowledging long-standing findings that, for both task and non-task topics, subordinates prefer supervisory communication that is accepting and encouraging rather than neutral or negative (Redding and Tompkins 1988), Millennials' need for communication from supervisors (and coworkers) that is positive in valence and affirming in content feels burdensome to many senior and seasoned organizational members. Popular literature and academic sources have argued that this need for affirmation derives from the constant flow of supportive messages Millennials have received from parents, teachers, and coaches throughout their childhood (Alsop 2008; Hill 2002).

A second important communication issue for Millennials entering the workplace is their desire for open communication, and lots of it-again, more so than newcomers from previous generational cohorts, according to some empirical studies (Gursoy et al. 2008; Martin 2005; Remo 2006). For example, Millennials are unlikely to accept an organizational policy that information is communicated on a "need-to-know basis." Regardless of their low-level positions, Millennial workers feel a need to be kept in the loop of information (George 2008). Notwithstanding supervisors' traditional preference for communication with other supervisors and managers more than with subordinates, as well as supervisors' tendency to emphasize task instructions in their downward communication with subordinates more than socio-emotional content (Wert-Gray et al. 1991), some empirical research indicates that supervisors today are surprised by Millennials' expectation that supervisors freely share information such as strategic plans while they are being formulated by higher management (George 2008). Expectations of this sort may be associated with Millennials also not being intimidated by individuals who are more senior, either in age or in status. Popular literature suggests that as children, they were encouraged to befriend parents and friends of their parents (Howe and Strauss 2007). As teens, they became comfortable expressing their thoughts and opinions to adults, expecting credibility despite their young age and lack of experiences (Tapscott 1998). They also have been encouraged by their parents to challenge authority, and to assert themselves, asking for preferential treatment when they believe they can get it (Howe and Strauss 2007).

Initially, Millennials' expectations for frequent, supportive, and open communication, as well as their lack of formality regarding status, structure, or propriety, may cause senior level workers to feel disrespected by young workers whom they believe have not yet earned these considerations. Boomers may even resent Millennials' implicit and explicit requests for communication and information. What Millennials may not fully understand is that increased communication and knowledge is associated with increased responsibility. Future research should examine whether Millennials learn through interaction with others that they may not be ready for that level of responsibility (Pacanowsky 1988). Do they learn to moderate their expectations and communicative requests? Another possible outcome that research should examine is whether organizations change their communication policies as a result of Millennial expectations. In some cases, workers could become privy to strategic and other 
information that could make them more informed, more competent, and thus better partners with their organizations. Management may find that investing Millennials with more responsibility concerning broader issues fosters feelings of involvement, which is a necessary component for organizational attachment (Myers and Oetzel 2003). More involvement also may help keep Millennials from feeling bored by their work, a primary reason for their premature turnover, according to popular literature (Alsop 2008)

Increased organizational openness also might provide additional and important opportunities for frank communication and problem solving between Millennial workers and their supervisors. Enhanced interaction may lead to closer supervisor-subordinate working relationships, which also may be important for Millennials' long-term relationship with the organization. Some empirical research indicates that Millennials do not develop organizational commitment as more senior workers have (Pasieka 2009; Patalano 2008). Instead, some popular literature claims that, more than other generations, Millennials develop commitment to individuals, especially supervisors with whom they develop meaningful relationships (Marston 2007). If this claim is true, strong commitments to supervisors may change Millennials' much publicized (though not entirely accurately discussed) tendency to switch jobs and careers at every opportunity (e.g., Gursoy et al. 2008; Remo 2006).

Differences between Millennials' and other generations' beliefs about time also are worth noting for their communication implications. Empirical studies and polls have found that Millennials are impatient about becoming recognized as valuable contributors (Gursoy et al. 2008; Pew Research Center 2007). Millennials, much like Generation $\mathrm{X}$ employees, have a much shorter time horizon than Boomers (who typically occupy positions of organizational power). Popular literature claims that more so than in previous generations, they multitask, and view time as a valuable resource that should not be squandered (Deloitte 2009). Based on frequent praise from their parents and teachers, they have come to expect evaluation of their work to be based on the outcomes they produce, not based on the age, experience, or tenure of the person who produced them (Alsop 2008; Hill 2002). However, more senior workers may not share this perspective, which can spark conflict and distrust. Millennials have not fully appreciated that time on the job and "time in rank" can be crucial to perceptions of them as reliable by Boomer and Generation X coworkers. For example, Myers' (2005) study of municipal firefighters revealed that throughout probationary firefighters' first year with the department, fellow crew members monitored not only how the new firefighters performed on service calls, but also on more routine duties back at the station. Did they demonstrate a willingness to listen and display deference to their seniors? In general, as organizational members interact over time and across a variety of circumstances, they develop deeper work relationships and, typically, an ability and willingness to trust each other (Haas 1977). Over time, Generation X and Boomer workers will likely come to value the contributions that Millennials can make (Smola and Sutton 2002). Related, as Millennials themselves are promoted and are given more responsibility, they too may come to understand the importance of developing confidence in workers prior to delegating significant tasks and responsibilities. Thus, through ongoing interactions, Millennials may begin to realize the value of time for forging trust among coworkers and, concomitantly, may develop a shared sense of temporality unique to their team and organization (Ballard and Seibold 2003, 2004) with coworkers from other generational cohorts.

A third communication-related consideration for workplace interactions with Millennials is their comfort and ease in working in teams. Semiautonomous and self-managed work teams have become commonplace in organizations because they enhance innovation, increase productivity, and they often lower personnel costs (Lawler 1994; Lawler et al. 1995; O'Toole and Lawler 2006). Millennials' entry is fortuitous for these organizations because, according to empirical research and popular literature, more than previous generations, Millennials value teamwork and are accustomed to collaboration (Deloitte 2009; Gursoy et al. 2008; Raines 2002). Millennials report that working and interacting with other members of a team makes work more pleasurable (Alsop 2008), in part, a consequence of group-based learning and project groups throughout their years in school, and perhaps in part because more than previous generations, Millennials often socialize in groups as well (Howe and Strauss 2007). Millennial workers are likely to be actively involved, fully committed, and contribute their best efforts to the organization when their work is performed in a collaborative workgroup or team.

Organizations have noted a downside to teams, however, and for several reasons they are beginning to encourage Millennials to accomplish part of their work outside workgroup boundaries (Alsop 2008). First, as Alsop describes, Millennials find excessive comfort in team-based direction, oversight, and decision making. If they can work as members of a team, they can avoid the risk associated with independent thinking and decisions. While it is true some types of decision making can be improved in group contexts (Shaw 1981), a group-reliant mentality does not foster individual decision-making confidence, nor does it enable individuals to demonstrate their own creativity and ability. Another problem is that 
teamwork and group meetings take time. As most managers know, some decisions-even in Millennials' entry level positions-must be made quickly and without the benefit of group consensus.

In fact, Millennials themselves may not yet realize that part of the effectiveness of self-managed teamwork, and what may be the dark side of teamwork (Seibold et al. 2009), lies in the concertive control exerted by members within the group. Concertive control emerges when team members collectively develop their own control system (Barker 1993). Control is negotiated and manifested through formal and informal team-based interaction, causing members to develop a shared sense of responsibility for the team's success. Group members come to believe that they are empowered to gain compliance from other members, causing workers to conform to mutually agreed upon norms (Barker 1993). Future investigations could examine how Millennials respond to this type of group-based control when the team is composed of heterogeneous members with regard to age, seniority, and influence. Popular literature suggests that Millennials are rule followers (Howe and Strauss 2003). If this claim holds, they are more susceptible to this type of pressure. However, Millennials also are described as self-assured and individualistic (Pew Research Center 2007; Twenge 2009) and thus perhaps less prone to, even more verbally resistant to, these communicative forms of control in their workgroups. Management will need to assess how these characteristics translate into workgroup conformity and performance. Future studies may find that over time Millennials no longer require the comfort of the group setting and distributed decision-making, choosing instead to work more independently.

\section{Millennials and Communication/Information Technologies}

Millennials are the first generation to have been born into households with computers and to have grown up surrounded by digital media (Gorman et al. 2004; Raines 2002). Popular press and literature indicate that they are more comfortable with new interactive and networked media than are older generations (Deloitte 2009; Gorman et al. 2004; Pew Research Center 2007); they spend more time with media per week than do other generations (Consoli 2006; Pew Research Center 2007); and, while Millennials are heavy media consumers, a large number of them also create personal content on the Web (Marketing Charts 2007). Millennials' comfort with new media technologies suggests that they bring to the workplace potentially beneficial characteristics related to the use of communication and information technologies (CITs), such as the Web and instant messaging (Gorman et al. 2004; Tapscott 1998).

Many Millennials are entering workplaces that include virtual teams and telework (Hertel et al. 2005). Whether Millennials will be productive in these time- and spaceflexible working arrangements is unclear. Millennials are argued to have some attitudes that are compatible, and some attitudes that seem incompatible, with virtual organizing and telework. Popular literature indicates that Millennials have an affinity for CITs and computer mediated communication (CMC); they see work in flexible terms (especially where and when work is done); and they desire flexible work schedules to accommodate their desire for work-life balance (Randstad Work Solutions 2007; SHRM, 2009; Simmons 2008). These attitudes and aptitudes should make virtual organizing and telework attractive to Millennials. At the same time, Millennials desire high levels of supportive supervision and structure at work (Ondeck 2002), both of which may be difficult to obtain in geographically distributed and technologically mediated settings. Next we discuss Millennials relative to virtual organizations and telework, their use of CITs and CMC to break down organizational boundaries, and how organizations might tap Millennials' technology-related expertise for their strategic advantage.

As globalization and the prevalence of virtual organizations increase (Stohl 2001), Millennials are especially likely to take advantage and extend the use of CITs, and CMC specifically, to interact with other organizational members, customers, and suppliers. CMC is attractive to Millennials for many reasons including the way that CMC breaks down social boundaries by reducing the limitations of physical boundaries on people's social contacts (Postmes et al. 1998), increasing group participation (Fulk and Collins-Jarvis 2001), and flattening organizational hierarchies (Walther 1995). Decreased social status differences are inherent in this breakdown of social boundaries because CMC "muffles social context cues and hence social differences" (Dubrovsky et al. 1991, p. 138), thereby potentially leading to a more egalitarian workplace (Rice and Case 1983). Despite these potential outcomes, when social cues are reduced, messages can be distorted or less clear (Schulman 2000). CMC also does not eliminate all social and normative restraints (Postmes et al. 1998) and it even "may amplify cultural rhetorical differences" (St. Amant 2002, p. 196). Since there are important differences in values and attitudes between generations (Smola and Sutton 2002), many of which have been detailed in our discussion thus far, it is possible that CMC may intensify some generational differences. Future research should explore under what circumstances this happens, since the amplification of generational differences through $\mathrm{CMC}$ could be a significant problem for 
organizations as CMC becomes increasingly prevalent in the workplace.

Millennials' interactions with others in the workplace may also change the way older generations, and Millennials themselves, perceive and use CITs. Uncertainty is inherent in the diffusion and implementation of technologies in organizations, and organizational members typically look to reduce their uncertainties about these processes by consulting with influential others, or lead users (Rogers 2003). This is a role in which Millennials may proffer significant contributions to their organizations and coworkers. Gorman et al. (2004) have suggested that Millennials "could essentially be employee lead users" of CITs (p. 260), driving or supporting the implementation of workplace CITs and building competitive advantages for their organizations as a result of their intimate relationship and extensive experience with CITs. In effect, Millennials could become resident experts concerning CITs, offering their more senior coworkers opinions about what works, what can work, and how the organization can utilize CITs to improve operations and marketing. It is unclear to what extent older employees perceive Millennials as lead users of CITs in the workplace, and to what extent Millennials are able to advise, even mentor, older employees about CIT uses-prior to and during CIT implementation processes. Such interactions have the potential to influence intergenerational relations and the communicative attitudes and behaviors of organizational members (McCann and Giles 2006). Conversely, helping older workers with CITs may influence Millennials' own attitudes about these technologies. They may become aware of the limitations of CITs, such as reduced social cues in mediated communication which can negatively affect outcomes (Daft and Lengel 1984, 1986).

Since organizational members "influence and help shape each other's perceptions and use of media" through social processes (Contractor et al. 1996, p. 452), we can expect that Millennials will influence the use of CITs within organizations as they enter and negotiate membership in the workplace. At the same time, Millennials' use of CITs also may be changed by interactions with others in the workplace. Older cohorts, specifically Boomers and older generations, still make up the majority of workers. Thus, senior colleagues' use of CITs-lacking by comparison with Millennials (Randstad Work Solutions 2007) will likely influence, and perhaps limit, Millennials' ability to utilize CITs in their organizations and may reduce Millennials' job satisfaction. Future research in this area will need to shed light on the functionality of newer CITs in organizations, the impact of CIT use on older generations, and Millennials' potential to change the way CITs are used to communicate intra-organizationally, as well as for the strategic advantage of organizations. Research could also examine how Millennials' attitudes toward CITs change once they have experience in using CITs in the workplace (rather than just socially), and how older generations' attitudes toward CITs might change as a result of Millennials' influence in the workplace. Millennials may discover that newer technology is not always the most efficient, nor the best media for developing and maintaining workplace relationships (compared with face-to-face interactions with coworkers and customers).

\section{Millennials, Communication, and Adversity}

For the most part, the popular perception of Millennials is that they have grown up in "good" times: they were valued as children, and they expect their careers to meet their basic financial needs and indeed to provide comfortable lifestyles. While many Millennials have grown up in poverty and have not been so privileged (approximately 20\% of American Millennials; Child Trends Databank 2009), many other Millennials have experienced relatively comfortable lifestyles. These Millennials have been raised by extraordinarily involved parents who coached on the sidelines and often interceded on their children's behalf (Raines 2002). Empirical research demonstrates that these efforts have produced a generational cohort that is high on self-efficacy and is unusually self-assured (Twenge 2009; Twenge and Campbell 2001). George (2008) adds that these efforts to instill self-esteem coincided with a consumer shift in the marketplace toward a focus on the individual. Marketers targeted young people more intensely than ever before, riding the self-esteem movement to offer these youth products ranging from cell phones and iPods with personalized accessories, to designer fashions complete with designer price tags. Product manufacturers and retailers realized that parents - flush with credit and disposable income-were inordinately concerned with their children's image and willing participants in the rampant consumerism. Parents also valued their children's opinions as knowledgeable consumers, even involving them in grown-up purchases (from cars to family vacations). These experiences have contributed to Millennials' high expectations and achievement orientation: they expect to find work that is well paying and meaningful, and even to become famous, according to the popular literature (Alsop 2008; Marston 2007).

Some claim that Millennials "need a good recession" to realize just how good they have had it (George 2008). Save for the dot-com bust, many Millennials have lived in times of relative prosperity and economic expansion (Marston 2007) - until the global recession that began in 2008. What remains to be seen is whether years of protection and nurturing by well-meaning parents have left Millennials 
unable to cope with economic hardship, and whether coming of age during the current economic recession will affect them and their expectations as they enter the workplace. Will it make them grateful for a job, thus causing them to develop a stronger work ethic to retain it? Will they feel the need to work harder in order to excel in a more competitive economy? Or, will it have the opposite effects? Will the uncertainty related to their jobs cause them to be even less committed to their organizations and less hard working?

Some contend that aspects of the Millennials' value system may actually work in their favor, and to their employers' benefit during economic downturns (George 2008). Management experts note that, while money is important, Millennials do not see money as their only source of happiness. Like Generation X workers, they feel rewarded by work arrangements that offer them more flexibility and new technology (Martin 2005). However, empirical studies indicate that, more like Boomers, Millennials thrive on recognition and promotions, but they also expect to become involved in projects that have a major impact on the organization, soon after their organizational entry (Bosco and Bianco 2005; Gursoy et al. 2008). In addition, many Millennials are using this time of fewer jobs for added career exploration, such as assuming internships that offer opportunities to dabble in various career options. Another path for many Millennials who are not yet driven by pressure to support themselves or families is to treat the first years beyond their graduation from college as a time to extend their education with advanced degrees.

Some Millennials view their early adulthood as a time to make a difference in the world and in their community. If the right job is not available, many are volunteering for organizations such as the Peace Corps or AmeriCorps (Jacobson 2007; Stone 2009). Indeed, while the number of volunteers in the U.S. increased $2 \%$ between 2007 and 2008 , the number of volunteers aged 16-24, comprised mainly of Millennials, increased by 5.7\% (Koch 2009). Some Millennials appear to be content to volunteer, or work in low-paying jobs, as long as they can continue to live with their parents, or as long as their parents are able to subsidize their standard of living (Alsop 2008). What remains to be seen is whether these values will change over time as Millennials marry, have children of their own, and when, or if, the wellspring represented by their parents dries up.

At least two potential outcomes should be investigated that could result during the current problematic job market from Millennials' time spent traveling, volunteering, working as interns, or pursuing advanced degrees-outcomes that may have implications for the organizations in which they ultimately find employment. First, as a result of these experiences, Millennials may develop greater awareness of the world around them. During these experiences they are likely to have had exposure to cultural diversity, to have developed greater empathy for lower socioeconomic populations, and to become advocates for pressing societal issues (Pew Research Center 2007). When Millennials eventually enter organizations, as a result of these experiences they are likely to arrive with a wealth of experiences that may serve them well in their organizational roles. They may be more accepting of people from diverse ethnicities and backgrounds, and potentially more comfortable and more skilled in interacting with them. These experiences and skills may generalize to helping Millennials develop working relationships with coworkers, customers, and other organizational stakeholders (Mitchell et al. 1997). Second, as a result of the alternatives to full-time employment and especially internships, they probably will be more aware of career paths and options when they do enter organizations as full-fledged employees. The result could be that Millennials carefully select the career and job that will most please them now and in the long run. However, it is also possible that increased knowledge may only cause them to be more susceptible to the "job hopping" now ascribed to them (Pasieka 2009).

\section{Millennials' Achievement Orientations, Parental Communication, and Leadership Aspirations}

In the popular literature, one of the characteristics commonly attributed to Millennials, especially those with higher socioeconomic status, is a strong achievement orientation (Howe and Strauss 2003; Luthar and Becker 2002; Pew Research Center 2007). Although this may sound like a contradiction-that Millennials are willing to volunteer their services and they feel rewarded by recognition-it is not. Millennials want to be valued either as volunteers or in their work. They have relied on financial freedoms and material goods provided by their parents, but eventually will require salaries to maintain their high standards of living (Pew Research Center 2007). Thus, many parents of Millennials (mostly Boomers) are preparing their children for financially rewarding career paths. Driven by intense vocational socialization from parents (Myers et al. 2009), Millennials are focused on personal achievement and success (Pew Research Center 2007). In particular, many parents place pressure on Millennials to succeed (Howe and Strauss 2003). Some empirical sources indicate that these parents have high standards for their Millennial children, insisting they take advanced college prep classes, helping them to prepare for college placement exams, and encouraging them to apply 
to prestigious colleges (Luthar and Becker 2002). Many parents continue their close supervision and pressure as their children enter the job market. For instance, employers cite increasing parental involvement during job recruitment (Gardner 2007). For both parents and Millennials, the first job is expected to be the "initial payoff for all the planning, stress, and shared ambition" (Howe and Strauss 2003, p. 133) they have endured; so parents take an active role in their children's lives and continue to push them to achieve personal, material success. As previously mentioned, Millennials are eager to develop close relationships with their supervisors whom many consider to be their workplace parents, according to the popular literature (Alsop 2008).

Although previous generations may have significant career ambitions, most Millennials strongly agree that they are pressured to achieve (Ramey 2008). As a result of this perceived intense socialization from parents, Millennials place a high value on and expect personal achievement. According to one Pew study (2007), 64\% of Millennials say that getting rich is the most important goal in life for their generation, and another $17 \%$ cite it as their generation's second most important goal. What is not yet known is whether and how this pressure will affect Millennials' career strategies and interaction with coworkers.

Sadaghiani and Myers (2009) proposed that socializing communication from parents about leadership also might emphasize personal achievement and extrinsic (i.e., material) success. Messages such as, "Leadership experience looks good on résumés," and "Leaders get special recognition from their followers," are examples of self-centered discussions about leadership promoting extrinsic success. Parents' and Millennials' potential self-oriented messages focusing on extrinsic benefits associated with leadership, when combined with employers' expressed interest in hiring leaders (NACE 2006), might influence Millennials to place more value on egoism in leadership and to be motivated to lead for selfish, materialistic reasons rather than out of a desire to benefit followers, or for the intrinsic satisfaction of being a leader (Sadaghiani and Myers 2009). If an individual is motivated to lead only for personal benefit, he or she will likely not be able to effectively work for followers when most needed.

Based on their survey of 130 college juniors and seniors, and contrary to their expectations and to what is suggested by popular press reports, Sadaghiani and Myers (2009) found that parents did not emphasize egoism over altruism (i.e., selflessness and a concern for followers) in socialization communication about leadership. "Parents of Millennials do talk about and encourage egoism and valuing extrinsic benefits, but they also talk about and encourage altruism in leadership" (Sadaghiani and Myers 2009, p. 24; italics added). The researchers found that while there is a positive relationship between leadership socialization and altruistic leadership values, there is also a positive relationship between leadership socialization and both the value one places on extrinsic rewards and the expectancy that leadership will provide extrinsic rewards. It is likely that Millennials will actively seek leadership opportunities. As these young people become leaders, they will communicate altruistic values, but like previous generations, they are also likely to seek rewards for leadership roles. Future research should seek to understand Millennials' sources of leadership socialization more thoroughly, and the values Millennials communicate once they have achieved leadership roles.

Future research also should examine the potential connection between socialization about leadership and socialization about volunteerism, which is, as noted earlier, a common activity among Millennials. While some analysts contend that Millennials are self-centered, others argue that Millennials value community, civic duty, and volunteerism. For instance, some popular literature authors observe that Millennials are civic minded and collaborative (Jacobson 2007; Raines 2002), and have been bombarded with messages that they should serve their community. Similarly, a study by the Harvard University Institute of Politics (2008), found that $60 \%$ of Millennials report an interest in public service to help the country. The Center for Information and Research on Civic Learning and Engagement (2009) also reports that Millennials are volunteering at historically high rates. Their volunteerism might be linked to parents' leadership socialization if, as Sadaghiani and Myers (2009) found, parents are encouraging values related to altruism and helping others (at least from leadership roles). Future research should investigate the role parents play in instilling Millennials' civic values and motivations toward volunteering. Are Millennials who are socialized toward volunteerism more likely to volunteer, and are they more likely to hold altruistic leadership values? In turn, how do these values affect Millennials' leadership aspirations and leadership behaviors (including their discourse) when they enter the workplace and ascend to higher levels? Answers to these questions will be useful for understanding and anticipating Millennials' leadership behaviors, and for developing leaders.

\section{Conclusion}

Millennials have distinctive characteristics that may make interacting with them different from with previous cohorts, but each modern generation has arrived in the workplace with its own unique set of qualities (Noble and Schewe 2003; Wade-Benzoni 2002). For example, empirical studies support the stereotypes that Boomers are ambitious 
workaholics who may be critical of coworkers who do not share those values (McGuire et al. 2007), while Generation $\mathrm{X}$ workers are skeptics who like to work autonomously and notoriously dislike meetings and group work (Martin 2005). What may be most different about Millennials is the amount of attention they have received-not only from their parents, but from scholars, the popular literature, and the popular press. Scholarship related to Millennial organizational members can benefit by drawing on intergenerational communication research (e.g., Chen and King 2002; Williams et al. 1997), although even these studies have explored situational and other factors that amplify differences and stereotypical expectations. A more productive goal may be to focus on what each generation offers to team and organizational performance, and how these qualities affect workplace communication, behaviors, and relationships (McCann and Giles 2006). To date, the lack of such research is sadly noteworthy (McCann and Giles 2006).

As we have suggested, Millennials are likely to be acutely affected by globalization, communication and information technologies, economics, and socialization by very involved parents. They are likely to have different, often broader, perspectives about the world marketplace, supervisor-subordinate relationships, cultural diversity, performance of tasks, and ways that communication and information technologies can be used to enhance organizational performance and to maximize productivity. Many of these Millennial stances and behaviors can be viewed by organizations as opportunities rather than obstacles. The key for coworkers from older generations-especially those in positions of formal and informal power in organizations-will be interacting with Millennials with a desire to understand, rather than with the aim of criticizing how Millennials are different. Trust and supportiveness between Millennials and coworkers will encourage them to become more involved, committed, and better performing in their organizations (Albrecht et al. 1995; Peterson and Albrecht 1996). Future research should investigate the long-term effects of Millennials' membership in organizations. Which Millennial qualities have translated to favorable changes, for example? How have organizational members modified their communication to manage conflict between the cohorts? Another important area of research could examine how Millennials are affected by interaction with supervisors and coworkers. Will they adapt as they gain experience, and as a result of interaction with their Boomer and Generation X colleagues? Or, will they retain their positive qualities, remaining optimistic, team oriented, and committed to balancing personal and work life? Especially important, what are the effects of coworkers' relationships with Millennials on team performance and organizational productivity?
Open Access This article is distributed under the terms of the Creative Commons Attribution Noncommercial License which permits any noncommercial use, distribution, and reproduction in any medium, provided the original author(s) and source are credited.

\section{References}

Albrecht, T. L., Burleson, B. R., \& Goldsmith, D. (1995). Supportive communication. In M. Knapp \& G. R. Miller (Eds.), Handbook of interpersonal communication (pp. 419-449). Thousand Oaks, CA: Sage.

Allen, B. J. (1995). "Diversity" and organizational communication. Journal of Applied Communication Research, 23, 143-155.

Alsop, R. (2008). The trophy kids group up: How the Millennial generation is shaping up the workplace. San Francisco: JosseyBass.

Alsop, R., Nicholson, P., \& Miller, J. (2009). Gen Y in the workforce commentary. Harvard Business Review, 87(2), 43-49.

Alvesson, M., \& Willmott, H. (2002). Identity regulations as organizational control: Producing the appropriate individual. Journal of Management Studies, 39, 619-644.

Babcock, L., \& Laschever, S. (2003). Women don't ask: Negotiation and the gender divide. Princeton, NJ: Princeton University Press.

Ballard, D. I., \& Seibold, D. R. (2003). Communicating and organizing in time: A meso-level model of organizational temporality. Management Communication Quarterly, 16(3), 380-415.

Ballard, D. I., \& Seibold, D. R. (2004). Communication-related organizational structures and work group temporal experiences: The effects of coordination method, technology type, and feedback cycle on members' construals and enactments of time. Communication Monographs, 71(1), 1-27.

Barker, J. R. (1993). Tightening the iron cage: Concertive control in self-managing teams. Administrative Science Quarterly, 38, $408-437$.

Barker, J. R., \& Cheney, G. (1994). The concept and practices of discipline in contemporary organizational life. Communication Monographs, 61, 19-43.

Black, J. S., \& Ashford, S. J. (1995). Fitting in or making jobs fit: Factors affecting mode of adjustment for new hires. Human Relations, 48, 421-437.

Bosco, S. M., \& Bianco, C. A. (2005). The influence of maternal work patterns and socioeconomic status on Gen Y lifestyle choice. Journal of Career Development, 32, 165-182.

Bouwhuis, I., \& Rink, F. (2009, July). How mobility affects team performance: The role of voice in selection procedures on newcomer influence in teams. Paper presented at the annual conference of the Interdisciplinary Network for Group Research, Colorado Springs, CO.

Burgoon, J. K. (1993). Interpersonal expectations, expectancy violations, and emotional communication. Journal of Language and Social Psychology, 12, 30-48.

Burgoon, J. K., Berger, C. R., \& Waldron, V. R. (2000). Mindfulness and interpersonal communication. Journal of Social Issues, 56(1), 105-127.

"Cara" (2009, February 26). Millennials want work/life balance... Oh, the horror! Retrieved from http://careers.washington.edu/ Blog/2009/02/Millennials-Want-WorkLife-Balance-Oh-TheHorror

Carless, S. A., \& Wintle, J. (2007). Applicant attraction: The role of recruiter function, work-life balance policies and career salience. International Journal of Selection and Assessment, 15, 394-404.

Center for Information and Research on Civic Learning and Engagement. (2009). Downward trend in high school volunteering. Retrieved from http://www.civicyouth.org/? $\mathrm{p}=338$ 
Chao, G., O'Leary-Kelly, A., Wolf, S., Klein, H., \& Gardner, P. (1994). Organizational socialization: Its content and consequences. Journal of Applied Psychology, 79, 730-743.

Chatman, J. A., \& Flynn, F. J. (2001). The influence of demographic heterogeneity on the emergence and consequences of cooperative norms in work teams. Academy of Management Journal, 44, 956-974.

Chen, Y., \& King, B. E. (2002). Intra- and intergenerational communication satisfaction as a function of an individual's age and age stereotypes. International Journal of Behavioral Development, 26, 562-570.

Cheney, G., Christensen, L. T., Zorn, T. E., Jr., \& Ganesh, S. (2004). Organizational Communication in an age of globalization: Issues, reflections and practices. Prospect Heights, IL: Waveland Press.

Child Trends Databank. (2009). Retrieved October 18, 2009, from http://www.childtrendsdatabank.org

Clampitt, P. (2005). Communicating for managerial effectiveness (3rd ed.). Thousand Oaks, CA: Sage.

Collinson, D. L., \& Collinson, M. (1997). Delayering managers, timespace surveillance and its gendered effects. Organization, 4(3), 373-405.

Collinson, D. L., \& Hearn, J. (1994). Naming men as men: Implications for work, organization and management, gender. Work and Organization, 1(1), 2-22.

Consoli, J. (2006, June). 'Millennials' big for media biz. Media Week. Retrieved July 19, 2009, from http://www.mediaweek.com/ mw/news/recent_display.jsp?vnu_content_id=1002725634

Contractor, N. S., Seibold, D. R., \& Heller, M. A. (1996). Interactional influence in the structuring of media use in groups: Influence in members' perceptions of group decision support system use. Human Communication Research, 22(4), 451-481.

Cox, T. H. (1994). Cultural diversity in organizations. San Francisco: Berrett-Koehler.

Daft, R. L., \& Lengel, R. H. (1984). Information richness: A new approach to managerial information processing. In B. Staw \& L. L. Cummings (Eds.), Research in organizational behavior (Vol. 6, pp. 191-233). Greenwich, CT: JAI Press.

Daft, R. L., \& Lengel, R. H. (1986). Organizational information requirements, media richness and structural design. Management Science, 32, 554-571.

De Vos, A., Buyens, D., \& Schalk, R. (2003). Psychological contract development during organization socialization: Adaptation to reality and the role of reciprocity. Journal of Organizational Behavior, 24, 537-559.

Deloitte. (2009). State of the media democracy survey (3rd ed.). Downloaded on June 10, 2009, http://www.deloitte.com/us/ realitycheck

Dubrovsky, V. J., Kiesler, S., \& Sethna, B. N. (1991). The equalization phenomenon: Status effects in computer-mediated and face-to-face decision-making groups. Human-Computer Interaction, 6, 119-146.

Fulk, J., \& Collins-Jarvis, L. (2001). Wired meetings: Technological mediation of organizational gathering. In F. M. Jablin \& L. L. Putnam (Eds.), The new handbook of organizational communication: Advances in theory, research, and methods (pp. 624663). Thousand Oaks, CA: Sage.

Ganesh, S., Zoller, H., \& Cheney, G. (2005). Organizational resistance and globalization from below. Communication Monographs, 72, 169-191.

Gardner, P. (2007). Parent involvement in the college recruiting process: To what extent? (Research Brief 2-2007). East Lansing, MI: Michigan State University Collegiate Employment Research Institute.

George, L. (2008). Dude, where's my job? McLeans.Ca. Retrieved June 21, 2009, from http://www2.macleans.ca/2009/01/14/dudewhere\%E2\%80\%99s-my-job/
Gorman, P., Nelson, T., \& Glassman, A. (2004). The Millennial generation: A strategic opportunity. Organizational Analysis, 12(3), 255-270.

Greenbaum, H. H., \& Query, J. L., Jr. (1999). Communication in organizational work groups: A review and analysis of natural work group studies. In L. R. Frey (Ed.), The handbook of group communication theory and research (pp. 539-564). Thousand Oaks, CA: Sage.

Greenfield, P. M. (1998). The cultural evolution of IQ. In U. Neisser (Ed.), The rising curve: Long-term gains in $I Q$ and other measures (pp. 81-123). Washington, DC: American Psychological Association.

Gursoy, D., Maier, T. A., \& Chi, C. G. (2008). Generational differences: An examination of work values and generational gaps in the hospitality workforce. International Journal of Hospitality Management, 27, 458-488.

Haas, J. (1977). Learning real feelings: A study of high steel ironworkers' reactions to fear and danger. Sociology of Work and Occupations, 4(2), 147-170.

Harvard University Institute of Politics. (2008). Fall 2008 Survey. Retrieved from http://www.iop.harvard.edu/Research-Publica tions/Polling/Fall-2008-Survey

Herriot, P. (2002). Selection and self: Selection as a social process. European Journal of Work and Organizational Psychology, 11, 385-402.

Hertel, G., Geister, S., \& Konradt, U. (2005). Managing virtual teams: A review of current empirical research. Human Resource Management Review, 15, 69-95.

Hill, R. P. (2002). Managing across generations in the 21 st century: Important lessons from the ivory trenches. Journal of Management Inquiry, 11(1), 60-66.

Hill, L. A. (2008). Where will we find tomorrow's leaders? Harvard Business Review, 23, 123-129.

Howe, N., \& Strauss, W. (2000). Millennials rising. New York: Vintage Books.

Howe, N., \& Strauss, W. (2003). Millennials go to college: Strategies for a new generation on campus: Recruiting and admissions, campus life, and the classroom. Washington, DC: AACRAO.

Howe, N., \& Strauss, W. (2007). Millennials go to college (2nd ed.). Great Falls, VA: LifeCourse Associates.

Jablin, F. M. (1987). Organizational entry, assimilation, and exit. In L. Putnam, K. Roberts, \& L. Porter (Eds.), Handbook of organizational communication (pp. 679-740). Newbury Park, CA: Sage.

Jablin, F. M., \& Krone, K. J. (1994). Task/work relationships: A lifespan perspective. In M. L. Knapp \& G. R. Miller (Eds.), Handbook of interpersonal communication (2nd ed., pp. 621675). Thousand Oaks, CA: Sage.

Jacobson, W. S. (2007). Two's company, three's a crowd, and four's a lot to manage: Supervising in today's intergenerational workplace. Popular Government, Fall, 2007.

Jokisaari, M., \& Nurmi, J. E. (2009). Change in newcomers' supervisor support and socialization outcomes after organizational entry. Academy of Management Journal, 52, 527-544.

Kirby, E., \& Krone, K. (2002). "The policy exists but you can't really use it": Communication and the structuration of work-family policies. Journal of Applied Communication Research, 30(1), $50-77$.

Koch, W. (2009, July, 28). Economy low, 'generosity high': Ranks of volunteers expanded in 2008. USA Today, p. A1.

Lawler, E. E. (1994). From job-based to competency-based organizations. Journal of Organizational Behavior, 15, 3-15.

Lawler, E. E., Mohrman, S. A., \& Ledford, G. E. (1995). Creating high performance organizations: Practices and results of employee involvement and total quality management in Fortune 1000 companies. San Francisco: Jossey-Bass. 
Leets, L. (2001). Explaining perceptions of racist speech. Communication Research, 28, 676-706.

Luthar, S. S., \& Becker, B. E. (2002). Privileged but pressured? A study of affluent youth. Child Development, 73(5), 1593-1610.

Marketing Charts. (2007). Millennials demand on demand content. Retrieved from http://www.marketingcharts.com/television/mill ennials-demand-on-demand-content-4654

Marston, C. (2007). Motivating the "What's in it for me?" workforce: Manage across the generational divide and increase profits. Hoboken: Wiley.

Marston, C. (2009). Myths about Millennials: Understand the myths to retain Millennials. Retrieved June 23, 2009, from http:// humanresources.about.com/od/managementtips/a/millennial_myth. htm

Martin, C. A. (2005). From high maintenance to high productivity: What managers need to know about Generation Y. Industrial and Commercial Training, 37, 39-44.

McCann, R. M., \& Giles, H. (2006). Communication with people from different ages in the workplace: Thai and American data. Human Communication Research, 32, 74-108.

McGuire, D., By, R. T., \& Hutchings, K. (2007). Towards a model of human resource solutions for achieving intergenerational interaction in organizations. Journal of European Industrial Training, 31, 592-608.

McPhee, R. D., \& Zaug, P. (2000). The communicative constitution of organizations: A framework for explanation. Electronic Journal of Communication/La Revue Electronique de Communication, 10(1-2). http://www.cios.org/getfile/MCPHEE_V10N 1200

Miller, K. (2009). Organizational communication: Approaches and processes (5th ed.). Boston: Wadsworth Cengage Learning.

Miller, V. D., Johnson, J., Hart, Z., \& Peterson, D. L. (1999). A test of antecedents and outcomes of employee role negotiation ability. Journal of Applied Communication Research, 27, 24-48.

Mitchell, R. K., Agle, B. R., \& Wood, D. J. (1997). Toward a theory of stakeholder identification and salience: Defining the principle of who and what really counts. Academy of Management Review, $22,853-886$.

Moreland, R. L., \& Levine, J. M. (1982). Group socialization: Temporal changes in individual-group relations. In L. Berkowitz (Ed.), Advances in experimental social psychology (Vol. 15, pp. 137-192). New York: Academic Press.

Moreland, R. L., \& Levine, J. M. (2001). Socialization in organizations and work groups. In M. E. Turner (Ed.), Groups at work: Theories and research (pp. 69-112). Mahwah, NJ: Lawrence Erlbaum.

Myers, K. K. (2005). A burning desire: Assimilation into a fire department. Management Communication Quarterly, 18, 344384.

Myers, K. K. (2006). Assimilation and mutual acceptance. In J. Greenhaus \& G. Callanan (Eds.), Encyclopedia of career development (pp. 31-32). Thousand Oaks, CA: Sage.

Myers, K. K. (2009). Workplace relationships. In S. Smith \& S. R. Wilson (Eds.), New directions in interpersonal communication (pp. 135-156). Thousand Oaks, CA: Sage.

Myers, K. K., Jahn, J. L. S., Gailliard, B., Jahn, J., \& Stoltzfus, K. (2009, May). Vocational anticipatory socialization (VAS) related to science and math: A model of academic and career interests. Paper presented at the Organizational Communication Division of the International Communication Association, Chicago, IL.

Myers, K. K., \& Oetzel, J. G. (2003). Exploring the dimensions of organizational assimilation: Creating and validating a measure. Communication Quarterly, 51, 438-457.

National Association of Colleges and Employers (NACE). (2006). Job outlook 2007. http://www.naceweb.org/products/info_pages/ joboutlookreport.htm
Noble, S. M., \& Schewe, C. D. (2003). Cohort segmentation: An exploration of its validity. Journal of Business Research, 56, 979-987.

O'Toole, J., \& Lawler, E. E. I. I. I. (2006). The new American workplace. New York: Palgrave.

Ondeck, D. M. (2002). Intergenerational issues in the workplace. Home Health Care Management \& Practice, 14(15), 391-392.

Ott, B., Blacksmith, N., \& Royal, N. (2008, March 13). What generation gap? Job seekers for different generations often look for the same things from prospective employers, according to recent Gallup research. http://gmp.gallup.com

Pacanowsky, M. (1988). Communication in the empowering organization. In J. Anderson (Ed.), Communication yearbook 11 (pp. 356-379). Newbury Park, CA: Sage.

Pace, R. W., \& Faules, D. (1994). Organizational communication (3rd ed.). Englewood Cliffs, NJ: Prentice-Hall.

Pasieka, S. A. (2009). Exploring the changing workforce: Understanding and managing the generation of Millennial workers. Unpublished doctoral dissertation, Northcentral University, Prescott Valley, AZ.

Patalano, C. (2008). A study of the relationship between generational group identification and organizational commitment: Generation $X$ vs. Generation $Y$. Unpublished doctoral dissertation, Nova Southeastern University, Fort Lauderdale, FL.

Peterson, L. W., \& Albrecht, T. L. (1996). Message design logic, social support, and mixed-status relationships. Western Journal of Communication, 60, 291-309.

Pew Research Center. (2007). How young people view their lives, futures, and politics: A portrait of "Generation Next." http://people-press.org/report/300/a-portrait-of-generation-next

Postmes, T., Spears, R., \& Lea, M. (1998). Breaching or building social boundaries? SIDE-effects of computer-mediated communication. Communication Research, 25(6), 689-715.

Raines, C. (2002). Connecting generations: The sourcebook for a new workplace. Berkeley, CA: Crisp Publications.

Ramey, K. (2008). Undergraduate student perceptions of characteristics attributed to Millennial generation college students and implications for university recruitment and retention. Unpublished doctoral dissertation, Texas Tech University, Lubbock, TX.

Randstad Work Solutions. (2007). The world of work 2007. Retrieved July 26, 2009 from: www.us.randstad.com/the\%20world\% 20of\%20work\%202007.pdf

Redding, W. C., \& Tompkins, P. K. (1988). Organizational communication-Past and present tenses. In G. M. Goldhaber \& G. A. Barnett (Eds.), Handbook of organizational communication (pp. 5-33). Norwood, NJ: Ablex.

Remo, N. (2006). The effects of the reciprocity norm and culture on normative commitment for generation $Y$. Unpublished masters thesis, University of Windsor, Windsor, ON, Canada.

Rice, R. E., \& Case, D. (1983). Computer-based messaging in the university: A description of use and utility. Journal of Communication, 33, 131-152.

Rink, F., \& Ellemers, N. (2009, July). Security as a source of innovation: How position (in)security of existing team. Paper presented at the annual conference of the Interdisciplinary Network for Group Research, Colorado Springs, CO.

Robinson, S. L., \& Morrison, E. W. (2000). The development of psychological contract breach and violation: A longitudinal study. Journal of Organizational Behavior, 21, 525-546.

Rogers, E. M. (2003). Diffusion of innovations (5th ed.). New York: Free Press

Sadaghiani, K., \& Myers, K. K. (2009). Parents' influence on leadership values: The vocational anticipatory socialization of young millennial adults. Paper presented at the Western States Communication Association 80th Annual Convention, Mesa, AZ. 
Schulman, C. (2000, December 18). Email: The future of the family feud? Newsweek, p. 14.

Scott, C. R., Corman, S. R., \& Cheney, G. (1998). A structurational model of identification in the organization. Communication Theory, 8, 298-336.

Scott, C. W., \& Myers, K. K. (2010). Toward an integrative theoretical perspective of membership negotiations: Socialization, assimilation, and the duality of structure. Communication Theory, 30, 79-105.

Seibold, D. R., Kang, P., Gailliard, B. M., \& Jahn, J. L. S. (2009). Communication that damages teamwork: The dark side of teams. In P. Lutgen-Sandvik \& B. Davenport Sypher (Eds.), Destructive organizational communication: Processes, consequences, and constructive ways of organizing (pp. 267-289). New York: Routledge/Taylor \& Francis.

Sennet, R. (2000). The corrosion of character: The personal consequences of work in the new capitalism. New York: W. W. Norton \& Company.

Shaw, M. (1981). Group dynamics: The psychology of small group behavior. New York: McGraw-Hill.

Sias, P. M. (2009). Organizing relationships: Traditional and emerging perspectives on workplace relationships. Thousand Oaks, CA: Sage.

Simmons, K. S. (2008). Intergenerational communication in the workplace. The Online Journal for Certified Managers. May/ June 2008.

Slaughter, J. E., \& Zickar, M. J. (2006). A new look at the role of insiders in the newcomer socialization process. Group \& Organization Management, 31(2), 264-290.

Smola, K. W., \& Sutton, C. D. (2002). Generational differences: Revisiting generational work values for the new millennium. Journal of Organizational Behavior, 23, 363-382.

Society for Human Resource Management (SHRM). (2009). The multigenerational workforce: Opportunity for competitive success. Retrieved July 26, 2009, from http://www.shrm.org/ Research/Articles/Articles/Documents/09-0027_RQ_March_2009_ FINAL_noad.pdf

St. Amant, K. (2002). When cultures and computers collide: Rethinking computer-mediated communication according to international and intercultural communication expectations. Journal of Business and Technical Communication, 16(2), 196-214.

Stauffer, D. (1997). For generation Xers, what counts isn't work or all play. Management Review, 86(11), 7-19.

Stein, P. H., \& Beradinelli, E. (2009, April). Bridging the gaps among generations. Fire Engineering. www.FireEngineering.com

Stohl, C. (2001). Globalizing organizational communication. In F. Jablin \& L. Putnam (Eds.), The new handbook of organizational communication (pp. 323-375). Thousand Oaks, CA: Sage.
Stohl, C., \& Cheney, G. (2001). Participatory processes/paradoxical practices: Communication and dilemmas of organizational democracy. Management Communication Quarterly, 14, 349407.

Stone, A. (2009, April 13). 'Civic generation' rolls up sleeves in record numbers. USA Today. Electronic version. http://www. usatoday.com/news/sharing/2009-04-13-millenial_N.htm?csp=34

Tapscott, D. (1998). Growing up digital: The rise of the net generation. New York: McGraw-Hill.

Twenge, J. M. (2000). The age of anxiety? The birth cohort change in anxiety and neuroticism, 1952-1993. Journal of Personality and Social Psychology, 79, 1007-1021.

Twenge, J. M. (2009). Change over time in obedience: The jury's still out, but it might be decreasing. American Psychologist, 64, 28 31.

Twenge, J. M., \& Campbell, W. K. (2001). Age and birth cohort differences in self-esteem: A cross-temporal meta-analysis. Personality and Social Psychology Review, 5, 321-344.

Twenge, J. M., \& Nolen-Hoeksema, S. (2002). Age, gender, race, socioeconomic status, and birth cohort differences on the children's depression inventory: A meta-analysis. Journal of Abnormal Psychology, 111, 578-588.

Van Maanen, J., \& Schein, E. (1979). Toward a theory of organizational socialization. Research in Organizational Behavior, 1, 209-264.

Wade-Benzoni, K. A. (2002). A golden rule over time: Reciprocity in intergenerational allocation decisions. Academy of Management Journal, 45, 1011-1028.

Walther, J. B. (1995). Relational aspects of computer-mediated communication: Experimental observations over time. Organization Science, 6(2), 186-203.

Wentworth, D. K., \& Chell, R. M. (1997). American college students and the protestant work ethic. Journal of Social Psychology, 137, 284-297.

Wert-Gray, S., Center, C., Brashers, D. E., \& Meyers, R. A. (1991). Research topics and methodological orientations in organizational communication: A decade in review. Communication Studies, 42, 141-154.

Williams, A., Ota, H., Giles, H., Pierson, H. D., Gallois, C., Ng, S., et al. (1997). Young people's beliefs about intergenerational communication: An initial cross-cultural comparison. Communication Research, 24, 370-393.

Zemke, R., Raines, C., \& Filipczak, B. (2000). Generations at work: Managing the clash of veterans, Boomers, Xers, and Nexters in your workplace. New York: AMACOM American Management Association.

Zwilling, M. (2009, April 5). Millennials at work: Facebook or faceoff. http://blog.startupprofessionals.com/2009/04/millennialsat-work-facebook-or-faceoff.html 